\title{
The Middle Pleistocene terraces of the central Waveney valley, Earsham, south Norfolk, UK
}

by

Philippa Holmes ${ }^{1 \#}$, James Rose ${ }^{1^{*}, 2}$, Jonathan R. Lee ${ }^{1,2}$, Rene Barendregt $^{3}$, Ian Candy $^{1}$, James B. Riding ${ }^{2}$, Mark Lewis ${ }^{1,4}$.

${ }^{1}$ Department of Geography, Royal Holloway, University of London, Egham, Surrey TW20 0EX, UK

2 British Geological Survey, Keyworth, Nottingham NG12 5GG, UK

3 The University of Lethbridge, Lethbridge, Alberta, TK1 3M4, Canada

${ }^{4}$ Department of Earth Sciences, The Natural History Museum, Cromwell Road, London SW7 5BD, UK

${ }^{*}$ Author for correspondence

\# Sadly deceased, and on whose work this paper is based and to whom the paper is dedicated.

\begin{abstract}
Although substantial work has been done on the pre-glacial terraces of East Anglia, very little systematic work has been done to understand the origin of river terraces in East Anglia, that have formed since ice last covered of the region. This paper records the results of studies of exposures and borehole records in 'classical' Quaternary terrace landforms that are considered to have formed since the Anglian (MIS 12) Glaciation, in the middle Waveney Valley. These features have been examined in terms of their morphological and sedimentological properties, in order to provide a detailed record of their form and composition, understand their processes of formation, and identify their stratigraphical status. The results show that the main body of the highest terrace (Homersfield Terrace, Terrace 3 ) is not composed of river sediments, but of shallow marine sediments, and is a remnant of early Middle Pleistocene Wroxham Crag. River sediments, in the form of Anglian age (MIS 12) glaciofluvial Aldeby Sands and Gravels also exist in the area, as a channel fill, cut through the Wroxham Crag, and reflect outwash erosion and sedimentation from a relatively proximal ice margin to the west. The results mean that the interpretations previously presented for the terrace landforms of the middle Waveney valley are not applicable. The issue of why the terrace stratigraphy, hitherto identified in East Anglia cannot be related to that for the River Thames to the south and the rivers of Midland England to the west, still requires further research.
\end{abstract}

Keywords: Wroxham Crag; Middle Pleistocene; Lowestoft Till; Aldeby Sand and Gravel; Anglian Glaciation; glaciofluvial outwash; Norfolk, UK.

\section{1) Introduction}

\section{1) Scientific Issues}


Although the Quaternary geology of East Anglia has a long history of research, with findings that underpin much of our understanding of the Early and Middle Pleistocene of the southern North Sea region (in both Britain and continental Europe) there have, recently, been a number of significant new discoveries. For instance, we now know that the region experienced Mediterranean-style climate and the earliest human occupation in northern Europe (Parfitt et al., 2005; 2010; Candy et al., 2006; Lee et al., 2006); that a major river system (Bytham River, Rose, 1994, 2009; Westaway, 2009) flowed across the region from midland England prior to the first period of lowland glaciation, and that the geology of the Late Cainozoic shallow marine deposits in the southern North Sea region can be explained by the type of deposit that was transported by the 'preglacial' rivers (Rose et al., 2001; Rose, 2009). The regional context for these changes is shown on Figure 1.

Likewise, studies of the history of glaciation have been the subject of much debate, with propositions for up-to and including five pre-Last Glaciation (MIS 2) glacial incursions into the region (Perrin et al., 1979; Hamblin et al., 2000, 2001, 2005; Banham, 2001; Lee et al., 2004; Clark et al., 2004; Gibbard et al., 2009, 2012; Rose, 2009). Although innovative new research can explain much of the evidence in northern East Anglia (Lee et al., 2016), the issue of the number of glaciations across East Anglia and Midland England is still the subject of debate. Likewise the concept of the Bytham River has been questioned (Gibbard, 2009, 2013) or reinterpreted (Westaway, 2009), although the validity of the fluvial facies of the Cromer Forest-bed, or the Kesgrave Sands and Gravels which are the basis of preglacial rivers, remains accepted without question. The debate surrounding the existence of the Bytham river, and the associated sediment records (Gibbard et al., 2008; Westaway, 2009), has implications not only for the regional stratigraphy, but also for the early human occupation of Britain, as many of the early archaeological sites are associated with deposits of this former river system (Rose, 2009).

Clearly there is a need to resolve such major issues, either by further work, acceptable to all involved, or by the establishment of common standards for the interpretation of the evidence published so far. However one topic that has, hitherto, not received such attention is the origin of the river systems that currently drain East Anglia. This is particularly surprising as the River Thames, to the south of the area, has been the subject of substantial work (Bridgland, 1994; Bridgland et al., 2001), and has become an international standard for the response of integrated river systems to global climate forcing (Bridgland et al., 2004), and river catchments such as that of the Trent in Midland England have become a model for understanding the interaction between glaciation and river development during the late Middle and Late Pleistocene (White et al., 2010; Bridgland et al., 2014). Examination of the 1:50,000 scale maps of the British Geological Survey shows that catchments such as the Bure, Wensum, Yare, Waveney, Gipping, Stour, and Colne (Figure 2B) have variable numbers of aggradations and incisions (British Geological Survey, 1990, 1991, 1996a, b, 2001, $2010,2014)$, but in all cases the number formed in the equivalent period of time, generally taken to be since the Anglian (MIS 12) glaciation of the region, is less than the Thames and the Trent. However, of these systems, only the Wensum and Waveney have been the subject of a systematic, climate-constrained, study of incision and aggradation since their initiation (West, 1991; Coxon, 1979, 1993; Moorlock et al., 2000; Westaway, 2009). 
Examination of Figure 2 shows a symmetry between the glacially initiated valleys of East Anglia (Figure 2A), recognised by Woodland (1970), and the present drainage network (Figure 2B), implying that the radial drainage pattern of the eastern and southern part of the region was initiated by the hydraulic gradient of the glacier that spread across East Anglia, largely independent of the preglacial drainage pattern (Rose et al., 1985 Figure 18.5). In contrast the drainage network directed towards the Wash and Fen Basin reflects the slopes created by the excavation of this large depression by the glacier that deposited the extensive veneer of till across East Anglia and Midland England (Perrin et al., 1979, Rose et al., 1985). Whilst these general assumptions appear to be sound, there are few case studies of the initiation and development of these valleys. By far the most work done on this subject has been in the Waveney valley, where Coxon $(1979,1993)$ and Moorlock et al., (2000) have recorded the terrace landforms and examined their internal composition. Likewise, Westaway (2009) has examined this information within the context of the overall development of the drainage and uplift in the region. Nevertheless, the origin, history and anomalous character of the small catchments in East Anglia still require attention and the availability of high quality exposures into terraces of the River Waveney in the area of Earsham (Figures 1 and 2) provided an opportunity to further investigate this problem. The origin of the river terraces in the middle part of the Waveney valley, East Anglia and the associated antecedent landscape is the subject of this paper.

\section{2) Background to the area and previous Quaternary research}

The study site at Earsham is located west of Bungay in the Waveney valley (Figures 1 and 2) and is focussed on a number of exposures in terrace landforms located on the north side of the valley. In the study area, the valley trends SW - NE and the terraces have a surface elevation of between 17 and $10 \mathrm{~m} \mathrm{OD}$, rising above the floodplain and river level which is at about $8 \mathrm{~m}$ OD (Figure 4). The bedrock geology of the area is Cretaceous Chalk, overlain by silts, sands and gravels of the Crag Group, and sands and gravels and tills of the Corton and Lowestoft Glacigenic formations (Hopson and Bridge, 1987; Moorlock et al., 1996, Candy et al., 2008; Lee et al., 2015).

The River Waveney is a key drainage system in East Anglia, stretching west - east across the centre of the region from Lopham Fen to Lowestoft (Figure 3B), roughly along the line of the preglacial Bytham River, and provides a topographical depression between the Fen lowlands and the east coast (Figure 2B). Previous studies (Coxon, 1993; Moorlock et al., 2000) of the Quaternary deposits and landforms in the central part of the drainage basin have recorded a succession of terraces in the area (Figure 3 ) and Westaway (2009) has examined this information within the context of the overall development of the drainage and uplift in the region, proposing c. $16 \mathrm{~m}$ of uplift in the area since the formation of the highest terrace, with a tilt towards the east.

The deposits that fill the central part of the Waveney valley form the Third, Second and First Terraces of the Waveney river valley system (Moorlock et al., 1996, 2000) (Figure 3). The Third Terrace is also known as the Homersfield Terrace (Coxon 1993), and has been mapped in plan (Moorlock et al., 1996, 2000) (Figure 3A) and in long profile by Coxon (1993) and Moorlock et al. (2000) (Figures 3B and C). The Homersfield and associated terraces are restricted to a $25 \mathrm{~km}$ reach along the north side of the Waveney valley with Earsham located around the centre (British Geological Survey, 1996a). Consideration of both long profiles reveals anomalous 
gradients of part of the terrace surfaces (Figures 3B and C) with sections that are both significantly steeper and less steep than the present valley long profile.

Clarke et al. (1982) reported that the deposits in the area contains a lower, quartzoserich sand and gravel which they attributed to the Kesgrave Sands and Gravels (deposited by the preglacial River Thames), but which was correlated with the Bytham Sands and Gravels (deposited by the preglacial Bytham River) by Moorlock at el. (2000), and an upper flint-dominant sand and gravel attributed to 'much younger river terrace processes'. Coxon (1993, p 69) reported, however, that the sands and gravels of the Homersfield terrace contain 'ice-wedge casts, involutions (possibly loading structures), ice-collapse structures, and flow till facies of the Lowestoft Till. These structures...... indicate a cold climate with ice proximity during terrace formation'. He concluded by saying that 'the interdigitated Lowestoft Till suggests that the terrace was produced as a glaciofluvial outwash.... Therefore in terms of published work, the site under investigation is interpreted as part of an outwash terrace with a base composed of preglacial river deposits. In many respects, these features are the best studied terrace landforms in East Anglia (north of the Thames system), and as such form a model for other studies in the area (Rose, 2015). Despite this, Candy et al. (2008) described the study site in a Quaternary Research Association Field Study Guide and made the case that the sediments are early Middle Pleistocene shallow marine Wroxham Crag.

\section{2) Methods}

The area under consideration has been mapped to a $1 \mathrm{~m}$ resolution using LiDAR imagery (Figure 4), courtesy of Earsham Gravels Ltd. The sections studied are from within the Pheasant Walk Sand and Gravel Quarry owned by Earsham Gravels, and were cleared and logged at a number of sites in 2006-8, the locations of which are shown on Figure 4. A number of boreholes, drilled to understand the wider distribution of the exposed sediments are shown on Figure 10A. During the processes of section logging particular attention was paid to the texture and structure of the deposits, and the contacts between units. Colours were recorded using a Munsell Soil Color Chart. To determine water flow direction palaeocurrent measurements were made using a compass clinometer. All sections have been precisely levelled in relation to an Ordnance Survey datum. Borehole levels have been determined using LiDAR-derived contours.

Bulk samples were analysed in the laboratories at the Department of Geography, Royal Holloway, University of London (RHUL). Particle size of the $>63 \mu \mathrm{m}$ fractions was determined by wet and dry sieving (Gale and Hoare, 1991) and the $<63 \mu \mathrm{m}$ fractions using the Sedigraph method (Coakley and Syvitski, 1991). The calcium carbonate content of the samples was analysed using a calcimeter and gasometric method (Avery and Bascomb, 1974). Heavy mineral and clast lithological analyses were carried out, respectively, on the 63-125 $\mu \mathrm{m}$ and the 4-8, 8-16 and 16-32 mm fractions, using a petrological microscope and low-power stereo microscope (Gale and Hoare, 1991; Mange and Maurer, 1992; Walden, 2004; Nesse, 1991). The preparation of the samples for palynology followed the methodology of Riding and Kyffin-Hughes (2004). 
Thin sections were obtained from the diamicton unit using Kubiena tins and were prepared at RHUL using the approach of Lee and Kemp (1992) and Carr and Lee (1998). The samples were examined using a petrological microscope, under planeand cross-polarised light, at Queen Mary, University of London and described using the guidelines of Carr (2004). The orientation of elongate quartz grains was measured on a Petroscope.

In order to provide a possible chronology for the sediments at Earsham and relate them to the global Geomagnetic Polarity Timescale, sixteen samples were collected from fine grained units at Earsham (clayey silts, clay and diamicton) following the methodology set out in Barendregt and Duk-Rodkin (2004).

\section{3) Description}

\section{1) Geomorphology of the site and location of sample points}

The topography of the site is shown in Figures 3 and 4 . Figure 3 shows the interpretation of the terraces according to Moorlock et al. (2000) and the location of Figure 4. According to this interpretation, most of the area comprises Terrace 3 (Homersfield Terrace of Coxon, 1993) with a segment in the east forming Terrace 1. This is confirmed by the $1 \mathrm{~m}$ interval contour map of Figure 4 which shows Terrace 3 at elevations between 17 and $14 \mathrm{~m}$ OD and Terrace 1 at an elevation of around $10 \mathrm{~m}$ OD. Detailed consideration of the contour map shows however a more complex terrain with a SW - NE trending low-relief channel at the NW side of Terrace 3 and a similarly orientated crest to this terrace at the south, rising c. 2-3 m above the aforementioned channel.

The location of the six section logs (Figure 4) can be related to the terrace terrain with Sections 5 and 6 at the southern margin of the channel, Sections 1 and 3 in the main crest of the terrace (but only of the lower part) and Sections 2 and 4 in the northern edge of Terrace 1.

Figure 5 shows all the section logs, their facies codes and the location of the sample points used for particle size, clast lithology and heavy mineral analyses. This figure also identifies the three lithofacies units and the sub-unit, and the following text provides a description of these units along with reasoning behind of the interpretations. The characteristics of Lithofacies 1 and 2 are shown by photographs (Figure 6) and a detailed representation is shown by a sketch in Figure 7.

\section{2) Lithofacies Units}

\subsection{1) Lithofacies Unit 1}

This unit is represented in Sections 1, 3, 2 and 4 (Figure 5) and is shown in Figures 6 and 7 and Figure 1 of Candy et al., 2006). It comprises three lithofacies sub-units: a lower sand-dominated unit (1A), an upper gravel-dominated unit (1C) and an intercalated thin clay bed (1B). In the crest part of the terrace, this unit extends to the present surface, although this is not represented in the Section Logs. Unit $1 \mathrm{~A}$ comprises yellow (10YR7/8) and reddish yellow (7.5YR6/8) cross-bedded sands with discrete horizontal and trough-shaped erosion surfaces often enhanced by 
discontinuous gravel stringers; thin, horizontal sand beds and laterally continuous clayey silt drapes (Figures 6A and 7). The cross-bedding has a herringbone appearance with dips towards the NE and NW (Figure 7), a characteristic shown more clearly in Figure 1 of Candy et al. (2006) with dips towards the NE and SW. Unit 1B is a $10 \mathrm{~cm}$ thick bed of greyish brown (10YR5/2) silty clay observed only in Section 4 (Figure 5). Unit $1 \mathrm{C}$ is a yellowish brown (10YR5/6) and strong brown (7.5YR5/8) massive and cross bedded sand and gravel, with strong brown (7.5YR5/8) interbedded sands which, in this case dip towards the east, with a range between NNE and SE (Figure 6B).

Particle size analyses (Table 1) show all the sediment to be well sorted with the sands dominated by a medium sand mode $(250-500 \mu \mathrm{m})$. The sands and gravels are bimodal with medium sand and medium gravel modes, although the spread of the gravel mode extends into the fine and coarse fractions $(4-32 \mathrm{~mm})$. Clast lithologies (Table 2) are dominated by flints (c. $50-60 \%$ ) and quartzose (vein quartz and quartzite) rocks (c. 30\%). In addition, Carboniferous, Greensand and Rhaxella cherts are present in all cases, although in small percentages. Heavy minerals in all units are dominated by opaques and by garnet, which is ubiquitous in the non-opaque fraction (Table 3 ). Lithofacies $1 \mathrm{~A}$ is dominated by zircon and tourmaline, and Lithofacies $1 \mathrm{C}$ is dominated by amphiboles and epidote along with the zircon. Calcium carbonate is virtually absent throughout. The silty clay of Unit 1B contains a relatively sparse palynoflora (Table 4). The kerogen association is dominated by dark wood fragments with lower proportions of other, lighter-colour, plant material. The palynomorphs are dominated by the Carboniferous spores Densosporites spp. and Lycospora pusilla which together make up $82.1 \%$ of the sample. Jurassic pollen (Classopollis classoides) is also present, along with Betula from the Quaternary.

\subsection{2) Lithofacies Unit 2}

This unit is represented in Sections 5 and 6 (Figures 5 and 6) and comprises three sub-units. Lithofacies Sub-unit $2 A$ is a crudely bedded yellow brown (10YR6/8) sand, and is overlain by Sub-unit $2 \mathrm{~B}$ which is a grey (10YR5/1), chalky, diamicton clast (in the order of $1.2 \mathrm{~m}$ length, and $35 \mathrm{~cm}$ thick). The base of this clast is interbedded with the underlying sands and gravels. The diamicton is, in turn, overlain by a crossbedded sand and gravel which at lower levels is brownish yellow (10YR5/8), and in its upper part is light yellowish brown (10YR6/4) and yellowish brown (10YR5/4). In the area of Sections 5 and 6 , and to the north of these localities, Lithofacies $2 \mathrm{C}$ is up to 10 $m$ thick and reaches the surface beneath the low relief channel that forms the northern part of the terrace.

Sub-unit 2A has a bimodal gravel and sand particle size distribution, but the fractions are less well sorted than the sands and gravels in Lithofacies 1 (Table 1). It also has a higher percentage of flint, and lower percentage quartzose clasts than Lithofacies 1 , although all the chert lithologies are present (Table 2). The heavy mineral content is also different from underlying Units with higher proportions of amphiboles, micas and staurolite and lower frequencies of zircon (Table 3).

The diamicton in Section 5, which comprises Sub-unit 2B, is conspicuous within the sand and gravel deposits, and is a relatively common occurrence within this part of the quarry. The diamicton is typical of the chalky tills of East Anglia with a grey silt and 
clay matrix and high chalk clast and $\mathrm{CaCO}_{3}$ content (Table 1). Macrofabric analysis of the elongate clasts shows a weak NW-SE trend (Figure 8A), with a low angle of dip (shown also in the microfabric (Figures $8 \mathrm{~B}$ and $\mathrm{C}$ )). There are no obvious macroscale structures, other than interbedding with the underlying sand and gravels, but thin sections made from the deposit show parts that are massive and parts that are laminated (Figure 8D). Enlarged thin sections are very revealing with crushed grains and well-developed deformation structures in the form of rotation structures (van der Meer 1997; Carr, 1999), faults and planar shears, augen and folds (Figure 8E, F, G). The range of heavy minerals is different from all other units with the highest proportion of amphiboles and micas (Table 3).

The main body of Sections 5 and 6 comprise Sub-unit 2C, which consists of a bimodal, moderately sorted, trough and planar cross-bedded sand and gravel (Figure $6 \mathrm{E}$ and $\mathrm{F}$ ). Palaeocurrent directions determined from the cross bedding show a dip towards the east (Figure 5). The clast content is dominated by flint and quartzose lithologies with a significant degree of variability, but with lower quartzose contents than found in Sub-unit 1B. Clasts of the chalky diamicton are also common throughout this deposit. The heavy mineral content is also variable through the unit (Table 3), but has relatively high percentages of amphiboles, epidote and zircon, and relatively low percentages of tourmaline.

\subsection{3) Lithofacies Unit 3}

This unit is shown in Sections 2 and 4 and forms the uppermost unit of the succession. The topographical position of this sub-unit is resting on the northern side of Terrace 1 and against the bluff slope that separates Terrace 1 from the higher Terrace 3 (Figures 3, 4 and 5). This deposit consists of very pale brown (10YR7/4), horizontally bedded, fine medium sand. The heavy mineral distribution is different from all the other units in being mixed with moderate proportions of all lithologies (Table 3).

\section{4) Interpretation}

\section{1) Depositional environments}

\subsection{1) Lithofacies Unit 1}

Lithofacies 1 is dominated by well sorted sand and well sorted, bimodal sands and gravels (Figure 5), and has palaeocurrent directions that indicate a bi-modal style with flow towards the NW, NE (Figure 7), and SW (Candy et al., 2006, Figure 1). Likewise the sedimentary characteristics indicate rapid changes in flow regime with scour and channelling alternating with bedload and saltation transport, occasionally replaced by silt drapes that were deposited in still water, from suspension, onto stable surfaces. This combination of properties is typical of tidal current flow, with the constant sediment re-working to produce very well sorted deposits with reversed flow directions formed during ebb and flood tides, and fine grained sediment drapes formed during still water conditions brought about by tidal reversal (Reineck and Singh, 1973; Rose et al., 1999; 2001). The contrast between the sand dominated units of Subunit $1 \mathrm{~A}$ and the sand and gravel dominated Sub-unit $1 \mathrm{C}$ is also typical of tidal current sedimentation. This sedimentological change reflects a shift in the position of the tidal 
stream from the highest velocity flow-tracks responsible for the gravel bedload transport with sand rainout from suspension, and the lower velocity flow at the sides or bar-end of the tidal stream with sand transport as saltation load (Lee et al., 2006). The lateral continuity of some of the gravel and sand beds in Sub-unit $1 \mathrm{C}$ suggest structures up to tens of metres wide and two metres high, again supporting the tidal current genesis.

Further support for a shallow marine depositional environment is provided by the clast and heavy mineral composition (Tables 2 and 3 ) with materials derived from the Thames, Bytham, Ancaster and northern catchments (Figure 1). Particularly significant in this context is the mixture of cherts from the Carboniferous of the south Pennines (Bytham and Ancaster rivers), Rhaxella Chert from the Jurassic of east Yorkshire (northern rivers) or a northern glacial provenance, and Greensand Chert from Surrey (Mole-Wey tributaries of the pre-glacial river Thames). Tidal currents, reworking river-sourced deltaic or estuarine sediments, provide the most likely process for this mixing.

The silty clay of Sub-unit $1 \mathrm{~B}$ contrasts with the above, both in terms of the energy of the depositional process and the evidence provided by the palynomorph content (Table 4), which indicates a very restricted provenance source. The size distribution indicates rainout from suspension, and the very high clay content means that this process needed to take place over a relatively long period of time (as opposed to the deposition of silt). As such, deposition is likely to have been in a lake, and unlikely to be in a nearshore marine environment. Deeper, still-water in shore-distal locations could account for the high clay content, but in such circumstances the palynomorph assemblage would be expected to show a mixed provenance. This being the case, a marine, deep water depositional environment is unlikely.

The Carboniferous miospores that dominate the palynomorph assemblage are likely to be attributable to the headwaters of the Bytham River in the region of the southern Pennines (Riding, 2007). The relative scarcity of Jurassic and Cretaceous palynomorphs, which would be readily available between the Carboniferous outcrops and the study site, suggests that transport was by a non-entraining river in which all sediment-load was derived from the high stream-power headwater region and transported through the system to be deposited in the low-power depositional zone. In this context the most likely origin of this fine-grained deposit is in an overbank lake on a floodplain location and, should this be the case, the presence of the unit between Sub-units $1 \mathrm{~A}$ and $1 \mathrm{C}$ means that deposition took place at an interval of lower sea-level than that responsible for the tidal current deposits.

\subsection{2) Lithofacies Unit 2}

Lithofacies 2 varies from the lower unit in being less well sorted (Table 1), with diamicton clast inclusions (Figures 5 and 8 ) and a more variable lithological assemblage (Tables 2 and 3 ). The relatively mixed sorting of the sand and gravel beds is typical of braided river deposits with cross-bedded units indicating variable flow directions, but a predominant (Figure 5) flow towards the east. Some of the cross bedded units have a relatively high amplitude, suggesting bar-front deposition, although interrupted by channelling and structureless deposition. 
The lithological composition shows an increase of glacially sourced materials in both the heavy mineral and clast fractions, but the bulk of the deposit is similar to the underlying Lithofacies 1 , suggesting derivation from the existing unit. This inference is supported by channelling into Lithofacies 1 and the higher percentage angular flint and quartzose clasts, which are likely to be produced by glaciofluvial transport, or fluvial transport within a periglacial climate.

Sub-unit 2B is a diamicton that is similar in appearance to the chalky tills of East Anglia (Perrin et al., 1979). The glacial origin is supported by the clast and heavy mineral composition including lithologies from northern England and Scotland (Tables 2 and 3 ). The clast fabric from the diamicton suggests a NW-SE stress-field during the process of deposition (Figure $8 \mathrm{~A}$ ), but this is likely to be inherited as the micromorphology (Figure 8B - G) suggests a more complex depositional process. Microscale structures indicate both powerful sub-glacial tractive forces causing grain fracture, faulting, dilation and the production of rotational structures. There is also evidence for the presence of water flow through fissures in the deposit which resulted in the deposition of fine-grained laminae (Figure 8G). Taken together, this evidence suggests that the diamicton clast in Lithofacies 2 was derived from a traction till that was detached from a main sediment body, either within a glacial context or following glacial deposition. In either scenario, the detached fragment would have flowed or been rafted onto the sands and gravels of Sub-unit $2 \mathrm{~A}$, with which it subsequently became interbedded.

Sub-unit $2 \mathrm{C}$ also contains smaller clasts of the same diamicton. The whole of Lithofacies 2 is interpreted as a glaciofluvial or fluvial deposit transported by a (meltwater) river that flowed from the west to the east, either from a glacier within the catchment or as a powerful stream reworking glacial sediments both locally and elsewhere in the upper parts of the catchment. This process at Earsham first produced a deep channel within Lithofacies 1 , but this channel was subsequently filled almost to the level of the existing unit.

\subsection{3) Lithofacies Unit 3}

Lithofacies 3 consists of horizontally bedded sands resting on the zone of inflection between the Terrace 1 and the slope up to the higher Terrace 3 and is interpreted as wind-blown sand. The very well sorted nature of these deposits and skew of the particle size distribution towards the fine fraction, are typical of an aeolian deposit (Leeder, 1999; Hoare et al., 2002) and the dominance of fine and medium sand grains imply transport by saltation during episode of higher wind velocity. This interpretation is supported by the mixed nature of the heavy mineral assemblage which suggests derivation from all the adjacent lithologies and implies formation during a period of limited vegetation cover.

\section{2) Stratigraphical affiliations}

\subsection{1) Preliminary comments}

Lithological properties, tuned by the response of lithologies to source distribution and transport processes, have played a major part in correlating and comparing Quaternary sediments and the establishment of a lithostratigraphy (Rose, 2010). This 
approach has been adopted for the Late Cenozoic, Early and early Middle Pleistocene sediments of east and midland England. This has resulted in the identification of lithologies that are:

(a) dominated by clasts of local provenance along with far-travelled silt and sand grains (palynomorphs and heavy mineral suite) (Norwich Crag, Rose et al., 2001: Rose, 2009),

(b) dominated by far-travelled clasts and far-travelled sand grains linked to a river catchment (Wroxham Crag, Cromer Forest-bed, Kesgrave Sands and Gravels, Bytham Sands and Gravels, Rose et al., 2001; Rose 2009), and

(c) mixed provenance and variable durability clasts and sand grains explained by glacial entrainment, mixing and rapid dumping processes (Rose et al., 1976; Rose and Allen, 1977; Perrin et al., 1979).

These suites of lithologies can be related to the dynamics of the sediment systems with (a) relating to the low physical energy systems, high chemical energy systems and the transport of fine grained insoluble residue in suspension (precession forced processes - c. 2.6 Ma and earlier); (b) relating to high physical energy, but constrained predominantly to river catchments (which at this time were larger, prior to dismemberment by glaciation) (obliquity forced processes - c. 2.6 to c. $0.9 \mathrm{Ma}$ ) and (c) high physical energy, but with diverse sources determined by glacial flow paths (eccentricity forced processes with glacial-interglacial cycles - c. 0.9 Ma to present) (Rose, 2010).

This subdivision has imprecise boundaries because of variations during the operation of these forcing cycles and the fact that clasts and sand grains respond to the forcing processes at different rates. This can mean that one lithostratigraphical indicator can turn on and operate at a different time to another, and in eastern England the eccentricity driven system began around MIS 16 (c. 630 ka BP) (Rose, 2010). It also means that the system is very crude, but in the absence of other correlative methods it provides a basis for correlation and age, and has a sound scientific basis.

For convenience and comparison, the clast and heavy mineral properties of samples from the Earsham sections are shown in Figure 9, with the earliest units at the base and the youngest at the top. Whilst there are some obvious distinctions that characterise the different lithofacies, there are also some complications that need further consideration and are discussed below. These histograms are arranged according to the provenance of the clasts and heavy minerals. Thus there are groups that can be attributed to the Thames and Bytham river catchments and to the North Sea region which includes, in the heavy mineral assemblages (Lee et al., 2006), the Scottish provenance and in the clast assemblage the chatter-marked flints (Lee et al., 2002). However, in the clast assemblages, the Scottish provenance is labelled 'Glacial' as the dominant 'glacial' lithology is chalk and other non-durable rocks such as limestone, sandstone and ironstone, and these rocks are more common than clasts from the igneous and metamorphic provinces of Scotland which yield the characteristic heavy minerals.

\subsection{1) Lithofacies Unit 1 - Wroxham Crag}

Lithofacies Unit $1 \mathrm{~A}$ is characterised throughout by a well-mixed Thames, Bytham and Northern provenance, suggesting derivation from each of these geomorphic domains. The clast assemblage (Figure 9, Table 2) suggests that the deposit is part of the 
shallow marine Wroxham Crag Formation, and the particularly high ratio of quartzose rocks to flint suggests correlation with the How Hill Member (Rose et al., 2001). However the clast distribution in the upper sample (2930) of this Unit, and the heavy mineral distribution in the upper three samples $(2926,2957,2930)$ indicate a reduction in the Thames and Bytham component and an increase in the Northern sourced material. This suggests influx of glacially sourced sediment into the North Sea basin, to be re-worked and redistributed by tidal currents. It is interesting to note that this occurs earlier within the heavy mineral assemblage than within the gravel size assemblage, reflecting the lower energy required to transport the sand-size material to the North Sea basin.

Nevertheless, despite these differences, Lithofacies Unit 1 is lithologically distinctive; although heavy mineral sample 2926 diverges from the characteristic Wroxham Crag with a lithology similar to Lithofacies Unit 2 (clast properties remain typical of the Wroxham Crag). This sample point is also stratigraphically adjacent to the silty clay of Lithofacies 1B which is interpreted as a floodplain-lake sediment. It is possible that the 'anomalous' heavy mineral sand assemblage reflects a fluvial input associated with same river that deposited the silty clay.

\subsection{2) Lithofacies Unit 2 - Aldeby Sands and Gravels and Lowestoft Till clasts}

Lithofacies Unit 2 includes both fluvial sands and gravels and till clasts.

Geomorphological correlation with fluvial landforms and sediments further west which contain ice-contact structures (Coxon, 1993) indicates a glaciofluvial origin, related at least in part, to an ice margin in the area of Homersfield (Figure 3). In many respects the sands and gravels are lithologically similar to the underlying Wroxham Crag, (Figure 9) except that they contain a greater frequency of non-chatter-marked flint and a persistent trace of Jurassic and Cretaceous non-durable lithologies, all reflecting the glacially-derived component. The dominance of flint, derived respectively from the Chalk and the existing Wroxham Crag, indicates enhancement of the durable rock fraction, whilst the low frequencies of the non-durable lithologies indicates removal of the non-durable limestones, sandstones and ironstones by solution and abrasion. Adjacent glaciofluvial sands and gravels (Figure 3) are known as the Aldeby Sands and Gravels, and these are contiguous with Lithofacies 2 in the area between Earsham and Ellingham (Figure 3). For this reason, the sand and gravel sub-units of Lithofacies 2 are attributed to the Aldeby Sand and Gravels. The Aldeby Sands and Gravels from Leet Hill (Rose et al., 1999) are different, as they have a high chalk clast content reflecting lack of decalcification.

The till clasts are visually similar to the chalky till of eastern England, and comparison of this material in terms of the particle size, clast lithology and heavy mineral content shows that it has a North Sea/ Scottish Provenance Association (Lee et al., 2004a), and was transported to the Earsham area across the Wash and Fen Basin, then over the Cretaceous chalk escarpment (Perrin et al., 1979; Rose, 2009; Lee et al., 2011; 2016). The relatively high proportion of calcium carbonate in the matrix $(40.2 \%)$, chalk clasts $(8-16 \mathrm{~mm})$ in the bulk sample $(61 \%)$ and Jurassic clasts $(8-16 \mathrm{~mm})$ in the bulk sample $(7.1 \%)$ suggests correlation with the Lowestoft Till of the region (mean $\mathrm{CaCO}_{3}$ $32.1 \%$, chalk clast content range $(55-84 \%)$, Jurassic clast content $(8.5 \%)$ (Moorlock et al., 2000; Lee et al., 2004b). Likewise the percentage of amphibole (20.1\%) is similar 
to the Lowestoft Till (23.8\%, Perrin et al., 1979; 27.7\% Lee et al., 2004b) and the high frequencies of opaques is typical of the Lowestoft Till (Perrin et al., 1979).

However, the percentage silt in samples from Earsham is relatively high $(39.5 \%)$ and the clay fraction $(28.0 \%)$ is relatively low when compared to the Lowestoft Till in the Earsham region, and in these respects Lithofacies Sub-unit 2B is similar to the Walcott Till (Lee et al., 2004b). However, the Walcott Till has only been found in northeast Norfolk (Lee et al., 2004b), whereas the Lowestoft Till is widespread around the study area. The lower clay content may be explained by partial sorting during the transport and emplacement of the detached clast(s). Also, particle size analysis of other samples, not shown on Figure 5, show a degree of variability, and the difference is within the statistical range within the region indicated by Perrin et al. (1979). Therefore the diamicton is interpreted as Lowestoft Till.

\subsection{3) Lithofacies Unit 3 - Older Blown Sands}

The location of Lithofacies Unit 3 on the lowest of the Waveney terraces means that deposition took place after the formation and dissection of the terrace landforms. This unit is similar to a fine-medium grained blown sand deposit, in a similar geomorphological/ stratigraphical position, known as the Older Blown Sand (Moorlock et al., 2000), and has been interpreted as Late Devensian in age.

\section{5) Regional distribution and succession}

Following the analysis and interpretation of the section logs carried out in the sand and gravel quarry at Earsham, a borehole survey and sediment analysis was instigated to further interpret the origin of the sand and gravel deposits across the wider region. The location of these boreholes and their topographical position is shown on the map on Figure 10. Using the sorting, clast lithology and colour properties, the section logs were designated as to whether the material was Wroxham Crag or Aldeby Sands and Gravels (and other deposits if present), and the results are shown in the cross sections on Figure 10. This figure, along with the results from all the boreholes shown on Figure 10, have been used to derive a new model for the Quaternary geology of the terrace landforms in the north side of the Waveney valley around Homersfield, Earsham and Ellingham (Figure 11).

The succession of Quaternary deposits around Earsham is outlined below (Table 5), starting from the base and working up the succession:

Marine Silt and Sand. This is typically a dark grey (10Y/5, 5GY/4) silty sand with occasional marine shells. It is part of the Early/ early Middle Pleistocene Crag shallow marine sediments that were deposited when this region was a western extension of the North Sea. The grey colour of this deposit reflects the fact that it accumulated in a reduced environment and has been below the water table since deposition. In places these deposits contain marine shells. When shells are preserved the deposit is typically a dark brown (5YR4/4) sand and gravel with a low silt and clay content and has been partially-oxidized. This deposit is typical of the un- and partially-oxidized marine Crag deposits. More work needs to be carried out to determine whether it is Norwich or Wroxham Crag. 
Wroxham Crag. This is the dominant deposit of the area and underlies much of the terrace terrain. It is the equivalent of Lithofacies Unit $1 \mathrm{~A}, \mathrm{~B}$ and $\mathrm{C}$ and, like the sediments in the quarry sections is composed of beds of well-sorted gravel, sand and gravel, and well-sorted sand. The colour varies, but is typically strong brown (7.5YR5/6), reddish brown (5YR4/4) or brownish yellow (10YR6/8) and is dominated by quartz, quartzite and flint pebbles with a high proportion of well-rounded and rounded material. Near the surface, the flints are predominantly angular. Occasional brown silt beds form drapes across the sedimentary structures and are interbedded with the coarser units, and at a single location the unit includes a discrete silty clay bed (Sub-unit 1B). The well sorted sands and gravels are shallow marine tidal current deposits, the silty clay deposit is a floodplain lake deposit. Both represent deposition around the western margin of the North Sea basin with shallow marine or terrestrial sedimentation depending upon climatically controlled, sea-level variations.

Corton Formation. This is a complex of deposits laid down by a glacier that moved across the area from the north. It was the product of the first glaciation to cross the region. It is present in the succession beyond the Waveney valley and does not outcrop in any of the sections or boreholes used in this study.

Lowestoft Till. This is a clayey diamicton with chalk and flint pebbles in a dark grey matrix. It was deposited when the ice moved across the area from the west. It forms the surface deposit across much of the area beyond the Waveney valley.

Aldeby Sands and Gravels. This is a variably sorted sand and gravel and occupies a channel cut into the Wroxham Crag at the northern side of the terrace terrain. It is the equivalent of Lithofacies Unit 2A, B and C. Its distribution coincides with the shallow channel in the terrace surface that can be seen on Figure 4, and aspects of its regional distribution can be seen in Figure 3. It is typically a brownish yellow (6YR5/8) and yellowish brown (6YR5/4) sand and gravel dominated by flint pebbles with quartz and quartzite and occasional other lithologies such as chalk and sandstone. The pebbles are typically sub-rounded and sub-angular. In places there are large slabs of Lowestoft Till interbedded with the sands and gravels. This deposit is interpreted as a meltwater river deposit composed of material eroded from the Wroxham Crag and broken by frost action, and material derived directly from glacier transport. The river flowed to the east.

Also within the channel, but above this sand and gravel is a variable unit composed of sands, silts, silts and clays, and diamicton that has slumped down from the adjacent hillside. This material was formed when the meltwater river energy was reduced and subsequently when the meltwater river had ceased to flow.

Windblown sand. This is Lithofacies 3 and is a well sorted sand derived from the adjacent deposits and is located in sheltered positions on the terrace terrain.

River Alluvium and Peat. This is associated with the present river valley and floodplain and represents material transported by the present River Waveney, or formed as peat in poorly drained depressions on the floodplain.

\section{6) Discussion and Wider significance}




\section{1) The age of the deposits at Earsham, south Norfolk}

The age of the deposits and landforms of the middle Waveney valley can only be determined by correlation with other stratigraphical units from elsewhere in the region. Attempts were made to determine the age of the succession using palaeomagnetism of the silt layers and till clasts, and despite good results, this only showed the whole succession described from the section logs, to be younger than the Brunhes/ Matuyama (B/M) Boundary (0.78 Ma BP).

In order to determine the age, the key units in the succession are the Wroxham Crag and the Aldeby Sands and Gravels. The Wroxham Crag Formation is correlated with the 'Cromerian Complex' of the early Middle Pleistocene (Rose et al., 2001; Mathers and Hamblin, 2015) and the How Hill Member of this formation, with which Lithofacies 1 can be correlated in terms of clast content, means that it can be dated to around $0.78-0.5 \mathrm{Ma}$ BP. The Aldeby Sands and Gravels of the Anglian Glaciation are attributed to Marine Isotope Stage (MIS) 12.2 (Bassinot, 1994) dated to around $430 \mathrm{ka}$ BP. The Older Blown Sands are attributed to the Late Devensian (Moorlock et al., 2000) dated to around 26-17 ka BP (Clark et al., 2012).

\section{2) Palaeogeographical implications}

\subsection{1) Wroxham Crag - marine extent, sea-level, sediment provenance, and land uplift}

The bulk of the Wroxham Crag of the Earsham area represents a time when this part of eastern England was submerged below sea-level, and the coastal zone was being supplied by materials from the adjacent Bytham and Thames preglacial rivers (Figure 1) (Rose, 2009). The dynamic nature of the tidal currents, indicated by the sediment size distribution and sorting, suggests that the seas were relatively shallow and the palaeocurrent directions indicate that current flow was to the NW, NE, and SW, resulting in effective mixing of the transported sediments.

The presence of the silty clay (Sub-unit $1 \mathrm{~B}$ ) is interpreted as a lacustrine deposit, and implies that marine submergence was interrupted by a period of sub-aerial floodplain deposition. This is consistent with Quaternary climate change (Funnell, 1995), with high sea levels during the temperate episodes and lower sea-level during the colder periods (Briant et al., 1999; Lee et al., 2006; Lee, 2009). During periods of high sealevel the coastline would have been west of Earsham, at least as far as the distribution of Crag sediments shown on Figure 1, whereas during periods of low sea level the coastline would have been to the east, and for much of the time, within the region of what is now the North Sea. The Bytham River would have extended though the area towards that coastline (Figure 1). Climate would also have forced river dynamics, and it is likely that the sediment subsequently reworked in the shallow seas would have been transported during colder episodes, by rivers with a braided channel mode.

The preservation of the floodplain lake clays (Sub-unit 1B) must have occurred during a period of low sea-level, but during a warm temperate period with low physical energy and high chemical energy in which single-thread channels drained through fine-grained overbank floodplains. Such conditions are likely to have occurred at the end of a warmer episode when sea-level was falling but the river only had sufficient 
stream power to transport fine sediment through the system. It is highly probable that multiple changes of sea level have occurred during the formation of the Wroxham Crag, and Sub-unit 1B is just one surviving snapshot (Funnell, 1995).

With our understanding of global sea-level changes during the Quaternary (Funnell, 1995; Murray-Wallace and Woodroffe, 2014) it is unlikely that maximum high sealevels were much higher than the present, and that the elevation of the Wroxham Crag deposits up to c. $17 \mathrm{~m}$ a.s.l. is due to land uplift in response to isostatic unloading, caused by river and glacial erosion (Westaway, 2009). Although Westaway (2009) has made inferences about uplift rates and amounts in the region is it not possible to relate them to this work as his work makes no reference to the Wroxham Crag, and the date attributed to the formation of Terrace 3 (Homersfield Terrace) bears no relation to the findings of Coxon (1993) and this work.

\subsection{2) Glaciation and relationship to pre-existing relief and likely age}

The evidence for glaciation of the region takes the form of the clasts of chalky till held within Lithofacies Unit 2, and analysis of the clasts and particle size suggest that the most likely correlation is with the Lowestoft Till of the Anglian Glaciation of eastern England (MIS 12). There is very little direct evidence for glaciation, other than that preserved beyond the Waveney valley, as part of the regional plateau deposits (British Geological Survey, 1: 50,000 scale sheet 176, Lowestoft (1996); Moorlock et al., 2000). Two glacial formations exist (Corton and Lowestoft formations) in a layer-cake arrangement (Lee et al., 2015, Figures 64 and 66) associated, respectively, with a north-south flow trajectory (Corton Fm, Rose, 2009; Lee et al., 2015) and a west-east flow trajectory (Lowestoft Fm, Perrin et al., 1979). From the distribution of these deposits in East Anglia, these two formations would have extended across the study area, meaning that the Wroxham Crag sediments would have been covered by glaciogenic sediment. The association of the Lowestoft Till clasts with Aldeby Sands and Gravels that are incised into the Wroxham Crag suggests that the Waveney valley was excavated by meltwater from the Lowestoft Glaciation, a proposition that is supported by the recognition of ice-contact structures within the western end of the deposit in the area of Homersfield (Coxon, 1993).

Thus the Waveney valley (at least in the study area) has an origin in the Anglian Stage (MIS 12), and any links with the similar located and trending Bytham valley, are interrupted by a spread of glaciogenic sediment (Corton Fm, Lowestoft Fm). Nevertheless, such a spread across a pre-existing major valley is likely to have maintained a depression in the landscape, above the pre-existing feature, and this could have steered the location of meltwater drainage both sub- and pro-glacially.

\subsection{3) Origin of the Waveney Terraces}

The outcomes of this study provide an entirely new perspective on the origins of the terraces in the middle part of the Waveney valley, although in part, the model proposed by Coxon (1993) has been validated. The main body of the most extensive main terrace at Earsham (Terrace 3, Homersfield Terrace, Figure 3) is not composed of river deposits, but of shallow marine Wroxham Crag. A channel-fill at the north side of the Wroxham Crag deposits is a meltwater river deposit (Aldeby Sands and 
Gravels), but is a minor part of the landform complex, taking the form of a low relief channel in the wider terrace surface.

Strictly, the main terrace landform is not a river terrace. Although the planar relief is visually impressive, detailed surveying (Figure 4) shows a much more complex topography and, in terms of the Quaternary history of the area, a multi-process origin is required.

The main part of Terrace 3, which has a crest-like relief, is likely to have been formed either as i) a sea-bed tidal current terrain, ii) a glacially eroded terrain during the movement of the earliest ice sheet across the region or iii) a glacial meltwater eroded surface formed after glaciation, during the establishment of the Waveney valley. The fact that this is not a fluvial deposit, explains the anomalous long profile of this terrace (Figure 3B and C); a feature that has long attracted attention (Coxon, 1993, Moorlock et al., 2000).

The low relief channel that runs along the surface at the north side of the study area has a complex history. Initially, it appears to have been formed as a deep channel cut into the Wroxham Crag by Anglian age glacial meltwater, draining from the southwest to the northeast. This means that the postglacial Waveney valley had a low elevation (less than $7 \mathrm{~m}$ OD.) east of the Earsham area. Erosion then changed to sedimentation and the channel infilled with meltwater sands and gravels draining from an ice margin in the area of Homersfield. These sediments include clasts of Lowestoft Till, eroded either from the valley sides or derived directly from the glacier margin. Aggradation continued until it was close to the surface of the adjacent Wroxham Crag. This sediment fill must be associated with sedimentation in the area east of the channel, but it is not possible to determine what level this is likely to have reached. Borehole records indicate that the upper part of the infill includes interbedded slope deposits and still-water sediments, suggesting that discharges decreased progressively, prior to the channel being abandoned.

The detailed contour map of the study area (Figure 4) provides no evidence for Terrace 2 shown on the existing publications (Figure 3), (British Geological Survey, 1: 50,000 scale sheet 176, Lowestoft 1996; Moorlock et al., 2000), and the feature could not be identified by detailed field survey. However Terrace 1 is clearly visible on Figures 4 and 10 (Cross Section C). Borehole surveys through Terrace 1 show that it is underlain by Wroxham Crag and it is therefore interpreted as an erosional landform, produced as the River Waveney cut down to its present level. There is no evidence for its age other than the fact that it is overlain by the Older Blown Sands which are attributed by Moorlock at al., (2000) to the Late Devensian (MIS 2).

One of the main objectives of this study was to use the Waveney river terraces to further understand the development of the river systems in East Anglia, and in particular investigate how these rivers relate to Quaternary climate and sea-level change in the late Middle Pleistocene, in a similar way to that derived from terrace development along the Thames and Midland England. This study has, however, shown that the previously described terrace sequence in this region is actually a complex of landforms generated by a series of very different geomorphic processes and events. Terrace 3 is not in fact a fluvial landform and, in this section of the Waveney valley, the entire history of this river system is constrained to a single 
terrace unit (Terrace 1) and the recent alluvium. Whether the absence of a more extensive terrace sequence in this region is due to landform preservation or the nature of long-term fluvial response in this catchment is not currently clear. This study does clearly show, however, that the robust construction of a terrace sequence requires an integration of process-based geomorphology, sedimentology and an understanding of the stratigraphy, and antecedent conditions, of the river system in question.

\subsection{4) Colour of the sediments in Pheasant Walk Quarry, Earsham}

One of the most noticeable features of the deposits at Earsham is the sharp colour change within the sands and gravels part-way up the section (Figure 6F). The change is from yellow (10YR7/8) and reddish yellow (7.5YR6/8) at the base, to yellowish brown (10YR5/6) and strong brown ((7.5YR5/8) above. Sometimes the change coincides with a textural change (Figure 6F) and sometimes it is independent of textural change. It is proposed that this colour change is due to ground-water-level changes and chemical alteration, with the yellow and reddish yellow colours reflecting the concentration of oxidized iron minerals below the water table, and the removal of such minerals from above.

\section{7) Conclusions}

- A detailed survey of temporary sections, borehole samples and a high resolution contour survey at Earsham, south Norfolk provide the first detailed sedimentological study of the terrace landforms in the central part of the Waveney valley.

- The results of this study provide new insight into the Quaternary stratigraphy of the region and the origin of the terraces.

- The results show that the main body of the terrace landforms is composed of shallow marine, early Middle Pleistocene Wroxham Crag, and that the surface of the main body of the terrace is not a fluvial depositional landform, but an erosional surface formed either by shallow marine deposition or glacial or fluvial erosion.

- A deep channel-fill is identified at the north side of the terrace area, cut into the Wroxham Crag and infilled with glaciofluvial Aldeby Sands and Gravels, including, in places, clasts of Lowestoft Till that have been transported either from the ice margin or eroded from an adjacent hillside.

- The Aldeby Sands and Gravel channel-fill reaches a level close that of the surface of the Wroxham Crag (although it maintains shallow channel landform) and, superficially, the fluvial and shallow marine sediments give the impression of a single, large terrace landform, that has hitherto been called Terrace 3 or the Homersfield Terrace.

- The Homersfield Terrace, as a river terrace feature in the Waveney Valley, remains a valid concept but is less extensive than previously assumed.

- Dissection of the Wroxham Crag by the River Waveney has produced an erosional landform in the form of Terrace 1 . There is no evidence for Terrace 2 in the Earsham area.

- Wind-blown sands are preserved in sheltered locations in the region, reflecting aeolian redistribution of surface sands during periods of cold climate and minimal vegetation. 
- The terrace landforms of the Waveney valley show little similarity with those of the Thames and rivers of Midland England, and the development of the rivers of East Anglia during the late Middle Pleistocene still remains a problem.

\section{Acknowledgements}

We would like to thank Dr. Mark Stephens for introducing us to this site and Mr. Jim Bennett for allowing access to Earsham Gravels' quarry, and to allow the visit of the Quaternary Research Association to the quarry in September 2007. Thanks are also expressed to Jim and Shaun Bennett and Stephen Daws for continuing support with this work and permission to use the LiDAR imagery and the borehole records drilled as part of the aggregate survey. We also wish to than Tim Holt-Wilson for discussion in the field and during the drilling process, and for an incisive discussion of the findings proposed in this paper. Jonathan R. Lee and James B. Riding publish with the approval of the Executive Director, British Geological Survey (NERC). 